\title{
Azacitidine-Etoposide-Cytosine Arabinoside Combination Therapy In Older Acute Myeloid Leukemias
}

\section{Yaşlı Akut Myeloid Lösemi Hastalarında Azasitidin-Etoposid-Sitozin Arabinozid Kombinasyon Terapisi}

\author{
Senem Maral, Murat Albayrak, Çiğdem Pala, Abdulkerim Yıldız, Hacer Berna Afacan Öztürk, Pınar \\ Cömert, Osman Şahin, Birgül Öneç
}

Dışkapı Yıldırım Beyazıt Eğitim Araştırma Hastanesi, Hematoloji Bilim Dalı, Ankara

Dergiye Ulaşma Tarihi: 20.11.2019 Dergiye Kabul Tarihi: 11.08.2020 Doi: 10.5505/aot.2020.27576

\begin{abstract}
ÖZET
GIRİŞ ve AMAÇ: Akut myeloid lösemi(AML) yaşlı populasyonda sıklığı artan hematolojik malignitedir. Düşkün ve yaşlı hastalarda düşük yoğunluktaki tedaviler ve destek tedavisi uygun seçenekler olarak öngörülmektedir. On yıllarda hipometile edici ajanların kullanımı ile tedavi alanında olumlu gelişmeler yaşanmıştır. Çalışmamızın amacı merkezimizde ileri yaş AML hastalarımızda tedavi protokolu olarak uyguladığımız etoposit ve sitozin arabinozid(AraC) ile güçlendirilmiş azasitidin(AZA) kombinasyon rejiminin etkinliğini araştırmaktır. YÖNTEM ve GEREÇLER: Takip ettiğgimiz ileri yaşta ve performans durumu nedeni ile yoğun tedaviler için uygun olmayan yeni tanı AML hastaları retrospektif olarak incelenmiştir. Yaş, performans durumu, komorbidite açısından benzer iki grup oluşturulmuş, bir grup (n: 32) AZA-etoposit-AraC kombinasyonu ile tedavi edilirken, diğer grup (n: 32) düşük doz sitozin arabinozid ve/veya hydroksiüre ile tedavi edilmiştir. Gruplar kendi aralarında hematolojik parametreler, takip süresi, yanıt durumu ve sağ kalım açısından karşılaştııılmıştır. BULGULAR: Azasitidin kombinasyonu ile tedavi edilen sekiz hastada tam yanıt veya enaz parsiyel yanıt elde edilmiştir (p: 0.011). 30 günlük mortalite düşük yoğunluklu tedavi kolunda anlamlı olarak yüksek saptanırken, toplam sağ kalım açısından her iki grupta farklılık saptanmamıştır (sırasıyla p: 0.005 and p: 0.092) TARTIŞMA ve SONUÇ: Yoğun tedavileri alamayan, ileri yaş ve düşkün hastalar tedavi edilme açısından cesaretlendirilmelidir. Özellikle gelişmekte olan ülkelerde, hipometile edici ilaçlarla pahalı ve ulaşılması zor moleküllerin kombinasyonlarının yanısıra ucuz ve erişimi kolay moleküllerin kombinasyonlarına ihtiyaç vardır. Yanıt avantajı sağlayan azasitidin-etoposit-sitozin arabinozid kombinasyon tedavisini seçili hastalarda uygulanmasını öneriyoruz..
\end{abstract}

Anahtar Kelimeler: Azasitidin, Etoposid, Sitozin Arabinozid, Akut Myeloid Lösemi

\begin{abstract}
INTRODUCTION: Acute myeloid leukemia (AML) is a hematological malignancy that affects the older population. Low intensive therapies and the best supportive care are considered better options for frail and older patients. In last decades treatment approaches have been hopefull with the hypomethylating agents for this population. The aim of this study is to investigate the efficacy of combination therapy including azacytidine (AZA), etopocide and cytosine arabinoside(Ara-C), which is used as standard care for unfit and older AML cases in our hematology department.

METHODS: Retrospectively, we analyzed our newly-diagnosed older AML patients who were ineligible for intensive regimens due to unfit performance status. Groups with similar age, ECOG performance status and comorbidity were compared in terms of hematological parameters, follow-up, response status and survival. While 32 patients were treated with a combined hypomethylating agent protocol, other patients (n: 32) received low intense therapy including low dose Ara-C and/or daily hydroxyurea (HU).

RESULTS: Eight patients who treated with combined protocol achieved complet remission and parsial remission least. (p: 0.011) While 30 day-mortality was found significantly higher in patients treated with the low intense therapy than AZA combined protocol, overall survival was found similar (resp. p: 0.005 and p: 0.092). DISCUSSION AND CONCLUSION: Treatment should be encouraged for older AML patients who are not eligible for intensive therapy due to comorbidities and poor performance. While combinations of HMA with new investigational therapies are promising strategies, there is a need for the investigation of new combinations of HMA with easily accessible agents for developing countries where expensive new agents are not available. With the survival and response advantage, AZA-etopocide-AraC combination therapy can be a treatment option for selected patients.
\end{abstract}


Keywords: Azacitidine, Etoposide, Cytosine Arabinoside, Acute Myeloid Leukemias

\section{INTRODUCTION}

Acute myeloid leukemia (AML) is a hematological malignancy which affects the old population with a median age at diagnosis of 70 years (1). Previous studies have shown that approximately $10 \%$ of the old AML population are alive at 5 years from diagnosis. There are prognostic and therapeutic challenges to dealing with these patients due to multiple comorbidities, age-related system disfunctions, low performance status and intolerance of chemotherapy. In daily practice, the decision for treatment is made by clinicians considering the age, co-morbidities and performance status of the patient. With the usage of hypomethylating agents(HMA), survival rates and quality of life have improved in AML cases ineligible for intense therapy. Combinations of HMA with new therapeutics are promising strategies currently (2-10).

While intensive chemotherapies are recommended for fit old patients who are able to tolerate the treatment, low intensive therapies and supportive care are considered better options for frail and vulnerable patients. More than half of older AML patients receive no therapy in 3 months after diagnosis $(11,12)$. Furthermore, patients who received intensive chemotherapy have been reported to have a high 30-day mortality rate (13). With the encouraging outcomes of previous reports, the aim of this study was to investigate the efficacy of a combination including azacytidine (AZA), etoposide and cytosine arabinoside (Ara-C), which is used as standard care for unfit or old AML in our Hematology Department. The outcomes of this combination therapy were compared with those of low-intense therapy in older AML patients who did not accept to receive the systemic treatment.

\section{MATERIAL AND METHODS}

\section{Patients and Treatment modalities}

A retrospective analysis was made of newlydiagnosed, treatment-naïve AML patients who were treated in our Hematology Department between 2010 and 2018. Patients were included in two groups according to treatment modalities. In first group, patients were treated with a combined hypomethylating agent (CHA) protocol which included AZA $75 \mathrm{mg} / \mathrm{m} 2$ subcutaneous (sc) injection for 7 days, etoposide $50 \mathrm{mg} / \mathrm{m} 2 / 2$ hours intravenous infusion (iv) for 3 days and cytosine arabinoside (Ara-C) $40 \mathrm{mg} / \mathrm{m} 2$ (sc) $/ 3$ days in every 28 days(Table 1.). The patients in the other group received low intense therapy (LIT) including low dose cytosine arabinoside(LDAC) 40 $\mathrm{mg} /$ day by sc injection for 10 consecutive days every 4 weeks and/or daily hydroxyurea (HU). The patients were evaluated according to age, comorbidities and ECOG functional status by the physician during the treatment decision. The similar two groups were formed in terms of age, comorbidity and performance.

\section{Response assessment}

Bone marrow biopsy was taken from the patients treated with the CHA protocol to assess the response to treatment after four courses. The response was determined for the two groups according to the criteria of the International Working Group (IWG) in AML. Duration of treatment, overall survival (OS), ORR, and the number of treatment-associated febrile neutropenic attacks were compared between the groups.

\section{Ethical approval}

All procedures performed in studies involving human participants were in accordance with the ethical standards of the institutional and/or national research committee and with the 1964 Helsinki Declaration and its later amendments or comparable ethical standards. As a standard of care/action our department, the patient records confirmed that all the study patients gave informed consent at the time of hospitalization and before the administration of chemotherapy and other relevant diagnostic/therapeutic standards of care. Approval for the study was granted by the Ethics Committee of Ankara Yıldırım Beyazıt Diskap1 Research and Training Hospital.

\section{Statistical analysis}

Statistical analysis was made using SPSS version 24.0 software (Chicago, IL, USA). In the comparison of independent variables with homogeneous distribution, the Independent Samples t-test was used for parametric variables 
and data were expressed as mean \pm standard deviation. Differences between the groups in respect of non-parametric continuous variables were investigated with the Mann- Whitney Utest. Data were expressed as median (min-max) values. Estimated probabilities of survival were calculated using the Kaplan-Meier method, and the log-rank test was applied to evaluate differences between survival distributions. All statistical tests were two-sided, and a p-value of $\leq 0.05$ was considered statistically significant.

\section{RESULTS}

Totally 64 newly-diagnosed, treatment-naïve AML patients (33 females, 31 males) were analyzed retrospectively. Thirty-two patients (n:32) were treated with CHA protocol, thirtytwo patients (n:32) treated with LIT. Thirteen patients in LIT group (40\%) received LDAC alone, 12 patients $(38 \%)$ with HU + LDAC combination and 7 patients $(22 \%)$ with HU. The mean age of patients was similar between the two groups (resp. CHA group and LIT group $76 \pm 3,92$ years versus $76 \pm 4,70$ p:0.977). ECOG PS was defined $\geq 2$ for all patients in two groups. Initial median blast count was found to be similar in both groups (CHA 50\% vs LIT 60\%, p: 0.678). No statistically significant difference was found between the groups in respect of the hemoglobin, platelet, white blood cell count ( $>0.05$ ). Cytogenetic and molecular prognostic factors were evaluated in 24 patients (75\%) (12 patients from each group). A normal cytogenetic risk profile was detected in 14 patients (CHA:9 vs LIT:5 patients) and a poor cytogenetic risk profile (complex karyotype) was noticed in 2 patients in the LIT group. The patient characteristics and laboratory results were summarized in Table 2.

The median duration of treatment was 3 months in the LIT-treated group. Mortality was seen in 5 patients $(15.6 \%)$ within 30 days of treatment due to severe disease. In the CHA group, the median duration of treatment was 4 months. The salvage therapy was not used for any patient who relapsed /refractory to CHA treatment. Mortality within 30 days of treatment was not seen in CHA protocol treated patients.

Overall survival of all patients was found statically similar between two groups (median OS: 8 months vs. 4 months; $p=0.092$ ) Bone marrow examination after 4 courses could be evaluated in 20 patients of the CHA group and response was achieved in 8 patients (25\%). Bone marrow biopsy was not performed to assess the response of the LIT-treated patients. All continued to receive the same therapy until death from diagnosis. Response to treatment was assessed according to persisting peripheral blasts counts. None of the LIT-treated patients were achieved response. Duration of therapy and response to treatment are summarized in Table 3.

Febrile neutropenic attack episodes were observed in CHA-treated patients more frequently. (CHA n:27, 84\% vs LIT n:17, 53\%). (median attack number of febrile neutropenia CHA: 2 versus LIT:1, p: 0.001) (Table 3). Granulocyte stimulating agents were not administered to patients during neutropenic episode. Appropriate supportive care with transfusion was applied as necessary in both groups.

Table 1: Protocol of combination therapy

\begin{tabular}{|l|c|c|c|c|c|c|c|}
\hline & $\begin{array}{c}\text { Da } \\
\text { 1 }\end{array}$ & $\begin{array}{c}\text { Da } \\
\text { y2 }\end{array}$ & $\begin{array}{c}\text { Day } \\
3\end{array}$ & $\begin{array}{c}\text { Day } \\
4\end{array}$ & $\begin{array}{c}\text { Day } \\
5\end{array}$ & $\begin{array}{c}\text { Day } \\
6\end{array}$ & $\begin{array}{c}\text { Day } \\
7\end{array}$ \\
\hline $\begin{array}{l}\text { Azacitidi } \\
\text { ne } \\
75 \mathrm{mg} / \mathrm{m} 2\end{array}$ & + & + & + & + & + & + & + \\
\hline $\begin{array}{l}\text { Etoposide } \\
50 \\
\mathrm{mg} / \mathrm{m} 2\end{array}$ & + & + & + & & & & \\
\hline $\begin{array}{l}\text { (Ara-C) } \\
40 \\
\mathrm{mg} / \mathrm{m} 2\end{array}$ & + & + & + & & & & \\
\hline
\end{tabular}

Azacitidine $75 \mathrm{mg} / \mathrm{m} 2$ subcutaneous (sc) injection for 7 days, etoposide $50 \mathrm{mg} / \mathrm{m} 2$ intravenous infusion (iv) for 3 days and cytosine arabinoside (Ara-C) $40 \mathrm{mg} / \mathrm{m} 2$ (sc) for 3 days in every 28 days.

Table 2:Characteristics of patients

\begin{tabular}{|c|c|c|c|c|c|}
\hline & \multicolumn{2}{|c|}{ CHA } & \multicolumn{2}{|c|}{ LIT } & \multirow[t]{2}{*}{$\mathrm{p}$} \\
\hline & \multicolumn{2}{|l|}{$\mathrm{n}$} & \multicolumn{2}{|c|}{$\%$} & \\
\hline LDAC & & & \multicolumn{2}{|l|}{13} & \\
\hline $\mathrm{HU}$ & & & \multicolumn{2}{|r|}{22} & \\
\hline $\mathrm{HU}+\mathrm{LDAC}$ & & & \multicolumn{2}{|l|}{12} & \\
\hline Male & 18 & (56) & 15 & (47) & \\
\hline Female & 14 & (44) & 17 & (53) & \\
\hline $\begin{array}{l}\text { Mean Age } \pm \text { SD, } \\
\text { years }\end{array}$ & \multicolumn{2}{|c|}{$76 \pm 4,7$} & \multicolumn{2}{|c|}{$76 \pm 3,9$} & 0.977 \\
\hline $\begin{array}{l}\text { Median Wbcx } 10^{3} \\
\text { (IQR) }\end{array}$ & \multicolumn{2}{|c|}{$4.1(1.8-28.0)$} & \multicolumn{2}{|c|}{$9(3.2-46.5)$} & 0.055 \\
\hline $\begin{array}{l}\text { Median Hb g/dl } \\
\text { (IQR) }\end{array}$ & \multicolumn{2}{|c|}{$9(8.1-10.2)$} & \multicolumn{2}{|c|}{$8.4(6.9-9.3)$} & 0.063 \\
\hline $\begin{array}{l}\text { Median Pltx } 10^{3} \\
\text { (IQR) }\end{array}$ & \multicolumn{2}{|c|}{$60(35-125)$} & \multicolumn{2}{|c|}{$48(29-71)$} & 0.101 \\
\hline $\begin{array}{l}\text { Median blast } \\
\text { Count\%(IQR) }\end{array}$ & \multicolumn{2}{|c|}{$50(40-70)$} & \multicolumn{2}{|c|}{$60(40-90)$} & 0.678 \\
\hline
\end{tabular}


CHA: Combine Hypomethylating gent LIT: Low Intensive Therapy, LDAC: low dose cytosine arabinoside HU: hydroxyurea, Wbc:White blood counts, Hb:Hemoglobin, Plt: Platelets

Table3: Evaluation of treatment response

\begin{tabular}{|l|c|c|c|}
\hline & CHA & LIT & $\mathrm{p}$ \\
\hline $\begin{array}{l}\text { 30-day } \\
\text { mortality }\end{array}$ & 0 & 5 & 0.005 \\
\hline $\begin{array}{l}\text { \#Median } \\
\text { Febrile } \\
\text { neutropenia } \\
\text { (IQR) }\end{array}$ & $2(1-2)$ & $1(0-1)$ & 0.001 \\
\hline $\begin{array}{l}\text { Treatment } \\
\text { time, } \\
\text { month } \\
\text { (IQR) }\end{array}$ & $4(2.5-5.5)$ & $3(1.5-4)$ & $>0.05$ \\
\hline $\begin{array}{l}\text { OS, month } \\
\text { (IQR) }\end{array}$ & $8(6.16-983)$ & $4(2.30-5.39)$ & 0.092 \\
\hline ORR(\%) & $8(\% 25)$ & 0 & 0.011 \\
\hline
\end{tabular}

\section{DISCUSSION}

The treatment of older patients with AML is limited and unsatisfactory. Although there have been developments in treatment in recent years, there is no standard approach for this population. The decision for treatment is made by clinicians based on the chronological age, performance status, and co-morbidity of the patients. The treatment goals for these patients who are not eligible for ASCT are to extend survival and improve quality of life by transfusion independence. Azacitidine, which is a DNA methyltransferase inhibitor, recommended for patients with high-risk MDS and AML patients (15-19). The aim of this combination protocol is synergize and increase the effect of AZA with etoposide and Ara-C which are antileukemic agents .

We thought that the use of this protocol would be effective for AML patients who are not suitable for intensive treatment. CHAtreated patients were observed to have longer OS than the LIT-treated patients.

Radujkovic et al first compared the efficacy of AZA and LDAC treatments in 65 AML patients with high bone marrow blast counts $(\geq 30 \%)$. Response and hematological improvement rates were reported to be low and similar in both treatment groups (p:0.39) with estimated 1-year survival rates of $15 \%$ and $13 \%$ in the AZA and LDAC groups, respectively (19).
In a large cohort, Dombret et al compared ORR and OS rates of AZA therapy alone and conventional care regimens (LDAC, supportive care only, standard induction chemotherapy). AZA therapy was reported to be more advantageous with an increased median OS (10.4 versus 6.5 months). ORR were not superior with azacitidine (27.8\% vs $25.1 \%$, $\mathrm{p}: 0.5384)$ (18). The results of that study confirmed the clinical observation that AZA can have meaningful clinical activity (e.g., transfusion independency) and improve survival, even if CR is not achieved.

Tombak et al investigated the efficacy and safety of AZA in Turkish AML patients with $>30 \%$ BM blasts. In that study, $39.4 \%$ of all the patients had received first-line therapy including intensive chemotherapy, hydroxyurea or low-dose cytarabine prior AZA. ORR of patients who were unresponsive to AZA therapy was $18.3 \%$ and $53.8 \%$ with median OS of 12 months. Febrile neutropenia was documented in $60.8 \%$ of the patients (20).

In a recent study by Onec et al. with fewer patients, it was suggested that combinations of AZA with etoposide and ARA$\mathrm{C}$ significantly increase response rates and prolong survival (21).

The current study combination of HMA therapy was observed to have survival advantage when compared with LIT therapy. When compared with previous studies, the results of the current study show that $\mathrm{CR}$ rates were improved with combination rather than AZA therapy alone.

In the current study, CHA treated patients experienced febrile neutropenic attacks more frequently (p:0.001). Febrile neutropenia and infections may affect the overall survival rates. Increased febrile neutropenia episodes and prolonged hospitalization time seem the disadvantages of the therapy. Patients during neutropenic episodes should manage carefully.

This paper has limitations due to the retrospective design of the study. The cytogenetic risk factors that may affect the disease characteristics should be evaluated for all patients.

In conclusion, treatment should be encouraged for older AML patients who are not eligible for intensive therapy due to poor performance status. While combinations of HMA with new investigational therapies are promising strategies, there is a need for the 
investigation of new combinations of HMA with easily accessible agents for developing countries where expensive new agents are not available.

\section{Conflict of interest:None}

\section{References}

1. Juliusson G, Lazarevic V, Horstedt AS, et al. Swedish Acute Leukemia Registry Group. Acute myeloid leukemia in the real world: why population-based registries are needed. Blood. $119: 3890-99,2012$.

2. Sekeres MA, Othus M, List AF, et al. Randomized Phase II Study of Azacitidine Alone or in Combination With Lenalidomide or With Vorinostat in Higher-Risk Myelodysplastic Syndromes and Chronic Myelomonocytic Leukemia: North American Intergroup Study SWOG S1117. J. Clin. Oncol. 35: 2745-53,2017.

3. Garcia-Manero G, Atallah E, Khaled S.K, et al. Medeiros B.C. Final Results from a Phase 2 Study of Pracinostat in Combination with Azacitidine in Elderly Patients with Acute Myeloid Leukemia (AML). Blood 126: 453, 2015.

4. Garcia-Manero G, Sekeres M.A, Egyed M et al. A phase $1 \mathrm{~b} / 2 \mathrm{~b}$ multicenter study of oral panobinostat plus azacitidine in adults with MDS, CMML or AML with $30 \%$ blasts. Leukemia 31:2799-2806, 2017.

5. DiNardo C.D, Pratz K.W, Letai A et al. Safety and preliminary efficacy of venetoclax with decitabine or azacitidine in elderly patients with previously untreated acute myeloid leukaemia: A non-randomised, open-label, phase $1 \mathrm{~b}$ study. Lancet Oncol. 19:216-28, 2018.

6. Ravandi F, Alattar ML, Grunwald MR et al. Phase 2 study of azacytidine plus sorafenib in patients with acute myeloid leukemia and FLT3 internal tandem duplication mutation. Blood.121:4655-62, 2013.

7. Cooper BW, Kindwall-Keller TL, Craig MD et al. A phase I study of midostaurin and azacitidine in relapsed and elderly AML patients. Clin. Lymphoma Myeloma Leuk. 15: 428-32, 2015.

8. Swaminathan M, Kantarjian H, Daver N et al. The Combination of Quizartinib with Azacitidine or Low Dose Cytarabine is Highly Active in Patients (Pts) with FLT3-ITD Mutated Myeloid Leukemias: Interim Report of a Phase I/II Trial. Clin. Lymphoma Myeloma Leuk. 17: 3, 2017.

9. Navada S.C, Fruchtman S.M, Odchimar-Reissig $\mathrm{R}$ et al. A phase $1 / 2$ study of rigosertib in patients with myelodysplastic syndromes (MDS) and MDS progressed to acute myeloid leukemia. Leuk. Res. 64:10-16, 2018.

10. DiNardo CD, Stein AS, Fathi AT et al. Mutant isocitrate dehydrogenase (mIDH) inhibitors, enasidenib or ivosidenib, in combination with azacitidine (AZA): Preliminary results of a phase $1 \mathrm{~b} / 2$ study in patients with newly diagnosed acute myeloid leukemia (AML). Blood. 130:639, 2017.

11. Thein MS, Ershler WB, Jemal A, et al. Outcome of older patients with acute myeloid leukemia: an analysis of SEER data over 3 decades. Cancer. 119: 2720-27, 2013.

12. Medeiros BC, Satram-Hoang S, Hurst D, KQ Hoang, et al. Reyes, Big data analysis of treatment patterns and outcomes among elderly acute myeloid leukemia patients in the United States, Ann. Hematol. 94:1127-38,2015.

13. Appelbaum FR, Gundacke H, Head DR, Slovak ML et al. Age and acute myeloid leukemia, Blood 107 :3481-85, 2006.

14. Jones PA, Taylor SM, Wilson VL. Inhibition of DNA methylation by 5-azacytidine. Recent Results Cancer Res. 84:202-11,1983.

15. National Comprehensive Cancer Network. NCCN Clinical Practice Guidelines in Oncology. Myelodysplastic Syndromes Version 2.2017 . https://www.ncen. org/professionals/physician_gls/pdf/mds.pdf

16. Vidaza prescribing information. Celgene Corporation, Summit, NJ; Revision 8/2016. 2016.

17. European Medicines Agency. Vidaza (azacitidine). 2016:EMA/450923/2016

18. Dombret H, Seymour JF, Butrym A, Wierzbowska A, et al. International phase 3 study of azacitidine vs conventional care regimens in older patients with newly diagnosed AML with $>30 \%$ blasts. Blood. 12:291-9, 2015.

19. Radujkovic A, Dietrich S, Bochtler T, et al. Azacitidine and low-dose cytarabine in palliative patients with acute myeloid leukemia and high bone marrow blast counts--a retrospective single-center experience.Eur $\mathrm{J}$ Haematol. 93:112-7, 2014.

20. Tombak A, Uçar MA, Akdeniz A, Tiftik EN et al. The Role of Azacitidine in the Treatment of Elderly Patients with Acute Myeloid Leukemia: Results of a Retrospective Multicenter Study.Turk J Haematol. 33:273-280, 2016.

21. Onec B, Okutan H, Albayrak M, Can ES, et al. Combination therapy with azacitidine, etoposide, and cytarabine in the treatment of elderly acute myeloid leukemia patients: A single center experience. Jour of Can Res and Ther. 14:1105-11,2018. 